\title{
Niosome Encapsulated Bromelain Reduced IL-6 and TNF- $\alpha$ in LPS Induced in Mice
}

\author{
Siavash Hosseinpour Chermahini*1,2, Fadzilah Adibah Abdul Majid ${ }^{1}$, Azila Abdul Aziz ${ }^{1}$ and Roya Anvari ${ }^{2}$ \\ ${ }^{1}$ Department of Bioprocess Engineering, Faculty of Chemical Engineering, Universiti Teknologi Malaysia, Malaysia
}

${ }^{2}$ The University of Georgia, Kostava St. 77a, 0171 Tbilisi, Georgia

*Corresponding author: Siavash Hosseinpour Chermahini, Department of Bioprocess Engineering, Faculty of Chemical Engineering, The University of Georgia, Kostava St. 77a, 0171 Tbilisi, Georgia.

Received Date: December 20,2019

Published Date: January 14, 2020

\begin{abstract}
Skin inflammation is a pathogenic factor in ectodermal tissues, but applicable prescriptions like NSAIDS (non-steroidal anti-inflammatory drugs) have serious side-effects. Bromelain, as an alternative, is a more natural, safer, and more effective remedy with no side-effects. On the other hand, the existence of the stratum corneum (SC), which acts as a skin barrier, needs a novel method for the delivery of specific doses of bromelain to the desired action site. In this case, niosomes provide a practical system for the delivery of bromelain to the inflamed section of the skin. In this regard, lipopolysaccharide (LPS)-induced inflammation in mice was assembled in-vivo as a simulated model. The levels of two immune-modulatory regulators of cell responses to inflammation, i.e., interleukin-6 (IL-6) and tumour necrosis factor alpha (TNF- $\alpha$ ), were measured in response to treatment with niosome-encapsulated bromelain. Based on the results, the niosome-encapsulated bromelain significantly reduced the levels of IL-6 and TNF- $\alpha$ compared to other niosomal treatments such as bromelain alone and the vehicle (niosome alone).
\end{abstract}

Keywords: Ectodermal tissue; Niosome; Inflammation; Stratum corneum; Encapsulate; Bromelain

\section{Introduction}

Bromelain has been shown to demonstrate many potentially beneficial properties, both in-vitro and in-vivo, including those which are anti-oedematous, anti-thrombotic, fibrinolytic and profoundly anti-inflammatory. Clinical trials of bromelain have shown its effectiveness for treating various inflammation-based conditions. These include breast engorgement during lactation [1], osteoarthritis of the knee and hip [2,3], rhinosinusitis [4], sepsis in children [5], and urogenital inflammation [6]. There is experimental evidence to suggest that its effects on blood coagulation is promising, where increased serum fibrinolytic activity and prostaglandin levels have been noted when the levels of PGE2 and thromboxane A2 decreased, and this finding is crucial for the lowering of inflammation [7]. Bromelain has also demonstrated an ability to inhibit bacterial endotoxin LPS-induced NF-kB activity and the expression of PGE2 and Cox-2 [8,9]. To explain this mechanism, it was hypothesized that bromelain induces the cleavage of cell surface markers such as CD14 [10]. Among the secreted regulators of inflammation that are connected to the NF-
$\mathrm{kB}$ pathways and that respond to bromelain are IFN- $\gamma$, TNF- $\alpha$, IL- $1 \beta$, and IL-6. Depending on the context and micro-environment, these regulators can either stimulate tumour growth and invasion or activate immune responses and cause tumour regression [11-13]. The experimental evidence derived from an analysis of peripheral blood mononuclear cells (PBMC) from healthy volunteers as well as mouse macrophages suggests that bromelain can activate TNF- $\alpha$, IL-1 $\beta$, and IL-6 secretions in an IFN- $\gamma$-dependent mechanism $[14,15]$. IFN- $\gamma$ production, in turn, also increased in the presence of bromelain [16]. This data gave rise to the hypothesis that bromelain has the potential to activate a healthy immune system to ensure a rapid response to pathogens and cellular stress. However, in situations where the immune cells have already been stimulated, bromelain reduces the secretion of TNF- $\alpha$ and IL-6 [17]. Chobotova et al. (2010) [18] summarized that the role of bromelain in the regulation of inflammation in a cancer network occurs when there is an over-production of cytokines induced by inflammation. For instance, in the presence of LPS that stimulates an acute inflammatory reaction, bromelain has decreases the elevation of 
TNF- $\alpha$, IL-1 $\beta$ and IL- 6 expressions in human PBMC. Reductions in TNF- $\alpha$ and IFN- $\gamma$ expressions have also been observed in bromelaintreated inflamed tissues obtained from patients with inflammatory bowel disease (IBD) [19]. The described data demonstrate that the effects of bromelain on cytokine expressions depend on the presence of inflammation-inducing conditions. This underlines the potential of bromelain for the treatment of inflammation-based pathologies. However, the challenge that researchers are facing in terms of a transdermal therapeutic system (TTS) is the stratum corneum. The stratum corneum (SC) has been shown to be the main barrier to the transportation of nutritional compounds via the skin [20]. The delivery and release of bioactive materials like bromelain to different parts of the human body are practically carried out by nanocarriers. Several types of nanocarrier systems are available for transdermal drug delivery such as vesicular phospholipid gels (VPG) [21], microspheres [22], nanospheres [23], nanoliposomes [24] liposomes [25] archaeosomes [26], complexes [27], ethosomes [28], dendrimers [29] nanoemulsions [30], and niosomes [31]. The effectiveness of the delivery of bromelain to the affected sites depends on the delivery system used in the topical formulation [32]. Niosomes have specific characteristics for topical delivery and their technological and physicochemical characteristics have motivated researchers to consider them as ideal for the carriage of drugs for topical administration [33]. LPS can be a suitable agent for the simulation of inflammation conditions since it has been used to induce in-vitro and in-vivo inflammation [34]. To detect the LPSinduced inflammation, two cytokines, IL- 6 and TNF- $\alpha$, were selected in this study. IL- 6 and TNF- $\alpha$ are immuno-modulating agents that act as regulators of host responses to infection, immune responses, inflammation, and trauma. They include various groups of soluble proteins, peptides, or glycoproteins which act as hormonal regulators or signalling molecules from nanomolar to picomolar concentrations [35]. Some of them are pro-inflammatory, and this is necessary to initiate the inflammatory response required for the recruitment of granulocytes and then, lymphocytes, to fight disease. Excessive inflammation, however, is sometimes the pathogenicity of certain diseases. Other cytokines are anti-inflammatory and serve to reduce inflammation and promote healing [36]. When inflammation occurs, the cells remain alive up to a certain point but will die afterwards. In this study, niosome-encapsulated bromelain was used as an effective compound for the reduction of IL- 6 and TNF- $\alpha$ level in LPS-induced inflammation in the skin around the knees of mice. In order to determine the effectiveness of the treatment in mice, the LPS-induced inflammation was treated with niosome-encapsulated bromelain after 4 hours of induction. The inflammation response was measured at 4 hours. This study showed that niosome-encapsulated bromelain is effective in reducing inflammation after 4 hours of post treatment.

\section{Materials and Methods}

\section{Chemicals and mice}

All the chemicals used in this study were purchased from Sigma Aldrich and Merck, unless otherwise noted. The Span (40,
60, 80), Labrasol, dicetyl phosphate, and chloroform used were also purchased from Sigma Aldrich. Bromelain was purchased from Merck, while the LPS from Escherichia coli (0111:B4) was purchased from Sigma Aldrich. The TNF- $\alpha$ kit (Catalogue Number RAB0476) and the IL-6 kit (Catalogue Number RAB0307) were purchased from Sigma Aldrich (USA). The analytical grade chemicals used in this study were purchased from Sigma Aldrich. The mice were purchased from Universiti Kebangsaan Malaysia.

\section{Preparation of niosome-encapsulated $10 \%$ bromelain $(\mathrm{W} / \mathrm{W})$}

The niosome was created based on the protocol of Arora and Sharma (2010) [37] with minor modifications. First of all, a mixture of the vesicle-forming agents, i.e., surfactant 60 and Labrasol, was dissolved in chloroform (a volatile organic solvent) in a roundbottom flask at a mole ratio of 1:1. The organic solvent was removed at a temperature of $45^{\circ} \mathrm{C}$ using a rotary evaporator (40 rpm), leaving a thin film of solid mixture deposited on the wall of the flask. This dried surfactant film was then rehydrated with $100 \mathrm{~mL}$ of aqueous-phase distilled water with gentle agitation for an hour to yield multi-lamellar niosomes. The mixture was probe-sonicated using a Fisher Scientific sonicator at an amplitude of $40 \mathrm{~m}$, energy of $2000 \mathrm{~J}$ and power of $30 \mathrm{~W}$ for two minutes to yield uniform nanoparticles of niosomes. In this research, $10 \mathrm{mg}$ of bromelain was added to a 50:50 mixture of span/Labrasol. A statistical analysis of all the niosomal formulations showed that this combination had the best stability and transport properties for topical delivery in the current study.

\section{The maintenance and stabilization of animals (Mice)}

All the procedures on animals followed the guidelines for animal treatment set by the Laboratory Animal Science Association of Malaysia (LASAM), and Laboratory Animal Resource Unit, Faculty of Medicine, Universiti Kebangsaan Malaysia. The ICR mice (8-10 weeks old; male mice: 28-30 g; female mice: 24-26 g) were purchased from Universiti Kebangsaan Malaysia. The mice were kept in pairs in small polypropylene cages $(14 \times 30 \times 13 \mathrm{~cm})$ with beddings of wood shavings. The animals were allowed free access to food and water at all times and were maintained on a 12-hour light and12-hour dark cycle in a controlled temperature $\left(20-25^{\circ} \mathrm{C}\right)$ and humidity ( $50 \pm 5 \%)$ environment for a week before use.

\section{Inflammation induction of mice with serial dilutions of LPS}

The serial dilutions of LPS were modified from the protocol of Freshney (2008) [38]. After mixing 1mg of LPS with $1 \mathrm{~mL}$ of deionized water (DIW) according to the manufacturer's instructions (stock LPS solution), serial dilutions of the LPS were performed from $12 \mu \mathrm{g} / \mathrm{mL}$ to $1.5 \mu \mathrm{g} / \mathrm{mL}(1.5 \mu \mathrm{g} / \mathrm{mL}, 3 \mu \mathrm{g} / \mathrm{mL}, 4.5 \mu \mathrm{g} / \mathrm{mL}, 6 \mu \mathrm{g} /$ $\mathrm{mL}, 7.5 \mu \mathrm{g} / \mathrm{mL}, 9 \mu \mathrm{g} / \mathrm{mL}, 10.5 \mu \mathrm{g} / \mathrm{mL}$, and $12 \mu \mathrm{g} / \mathrm{mL}$ ) by diluting the solution in an appropriate volume of deionized water. Then, the stabilized mice were given intra-articular injections of different concentrations of $\operatorname{LPS}(1.5,3,4.5,6,7.5,9,10.5,12 \mu \mathrm{g} / \mathrm{ml})$ into the skin area. Deionized water was used as a blank, while plasma 
without LPS induction was used as the control. After 4 hours, the blood was taken and the plasma was analysed for theIL- 6 and TNF- $\alpha$ response. Three groups of mice were prepared for the next experiment.

\section{IL-6 and TNF- $\alpha$ measurements}

The IL- 6 and TNF- $\alpha$ measurements were modified from the protocol of the manufacturer's instructions. After bringing all the reagents and samples to room temperature $\left(18-25^{\circ} \mathrm{C}\right), 100 \mathrm{ml}$ of a standard and sample $(0.24-0.28 \mathrm{~mL})$ were added into appropriate wells, which were then covered and incubated for 2.5 hours at room temperature with gentle shaking. Then, the solution was discarded and washed 4 times with wash solution (filling each well with 300 $\mathrm{ml}$ of a wash buffer using a multichannel pipette). After the final washing, the plate was inverted against clean paper towels. 100 $\mathrm{mL}$ of biotinylated antibody continued to be added to each well, which was then incubated for 1 hour at room temperature with gentle shaking. Then, the solution was discarded and the wash was repeated as before. This was followed by the addition of 100 $\mathrm{mL}$ of prepared streptavidin solution to each well, which was then incubated for 45 minutes at room temperature with gentle shaking.

Table 1: Active ingredients used for treatment.
Once again, the wells were washed and $100 \mathrm{~mL}$ of TMB One-Step substrate reagent was added to each well and incubated for 30 minutes at room temperature in the dark with gentle shaking. Finally, $50 \mathrm{~mL}$ of the stop solution was added to each well and was read at $450 \mathrm{~nm}$ immediately using a UV-based micro plate reader known as the BIO-TEK, Model ELx808.

\section{Niosome-encapsulated bromelain treatment}

Prior to the experimental work, the selected mice were stabilized for one week. Their weight and body temperature were recorded over the one-week period. Four groups containing 4 mice each were prepared and stabilized for one week. $0.24-0.28 \mathrm{~mL}$ of plasma was withdrawn from the veins of all the experimental mice as a control. After 4 hours, $7.5 \mu \mathrm{g} / \mathrm{mL}$ of LPS was injected into all the mice, except for the control group. Then, blood was extracted from all the mice and 4 hours rest prolong. The respective groups were treated with niosome-encapsulated bromelain, niosome alone, and bromelain alone. After 2 hours another volume of blood was extracted. All the blood samples were kept refrigerated overnight prior to analysis. The active ingredients used for the treatment are listed in Table1 below.

\begin{tabular}{|c|c|c|c|c|c|c|c|c|}
\hline No & Samples & Control $(\mathrm{mL})$ & Base Cream(g) & Bromelain(mg) & Niosome(mg) & NSAIDS(mg) & LPS( $(\mathrm{mg} / \mathbf{m L})$ & Vehicle(mg) \\
\hline 1 & Plasma(Control) & $0.24-0.28$ & - & - & - & - & - \\
\hline 2 & LPS & - & - & - & - & - & 7.5 & - \\
\hline 3 & Vehicle(-C) & - & 1 & - & - & - & - \\
\hline 4 & Bromelain & - & 1 & 25 & - & - & - \\
\hline 5 & $\begin{array}{c}\text { Niosome } \\
\text { Encapsulated } \\
\text { Bromelain 10\% }\end{array}$ & - & 1 & - & 20 & - & - \\
\hline 6 & $\begin{array}{c}\text { Hydrocortisone } \\
\text { (NSAIDS)(C) }\end{array}$ & - & - & - & - & 10 & - \\
\hline
\end{tabular}

\section{Optimization of niosome treatment time}

The selected mice were stabilized for one week. Their weight and body temperature were recorded. Four groups containing 4 mice each were prepared for stabilization. $0.24-0.28 \mathrm{~mL}$ of plasma was extracted from the veins of all the experimental mice as a control. After 4 hours, $7.5 \mu \mathrm{g} / \mathrm{mL}$ LPSwas injected into all the mice, except for those in the control group. In continue, after 4 hours of LPS induction, blood was extracted from all the mice. After 4 hours of rest, all the respective groups were treated with niosome-encapsulated bromelain. Then, blood was extracted every 15 minutes after treatment for 120 minutes. All the blood samples were refrigerated overnight prior to analysis.

\section{Results and Discussion}

\section{Selection of suitable concentration of LPS to induce inflammation in mice}

This experiment was carried out to evaluate the appropriate concentration of LPS to induce inflammation based on the response of IL- 6 and TNF- $\alpha$. Based on the in-vitro study, LPS concentrations of $7.5 \mu \mathrm{g} / \mathrm{mL}$ and $9 \mu \mathrm{g} / \mathrm{mL}$ were selected for the inflammation induction (Figure $1 \& 2$ ).

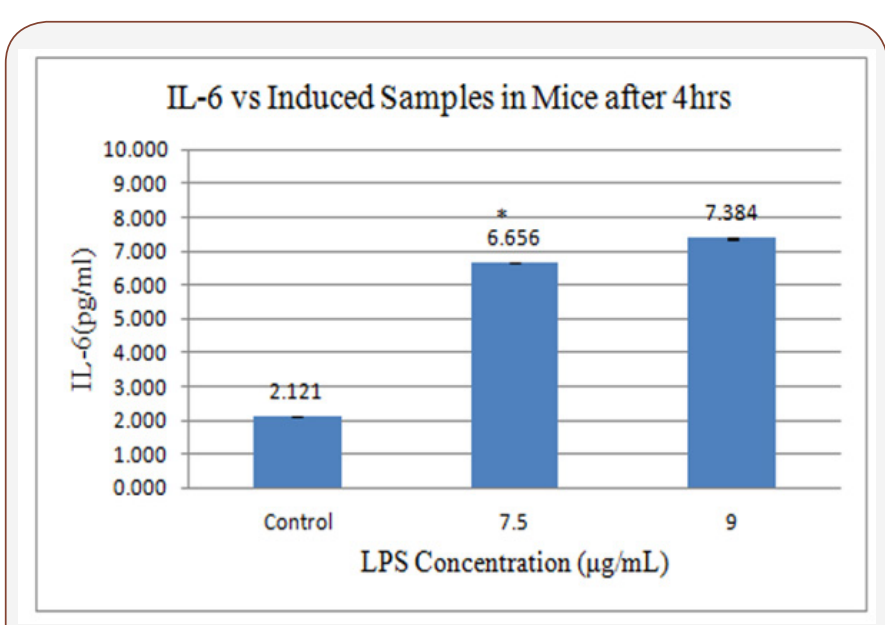

Figure 1:IL-6 responds after 4 hours LPS induction in mice.

Figure 1 shows the response of IL- 6 to different LPS concentrations. The response to $7.5 \mu \mathrm{g} / \mathrm{mL}$ LPS was $6656 \mathrm{pg} / \mathrm{mL}$ of IL-6, and to $9 \mu \mathrm{g} / \mathrm{mL}$ LPS, it was $7384 \mathrm{pg} / \mathrm{mL}$ of IL-6. Figure 2 shows the response of TNF- $\alpha$ against the LPS concentration. The response to $7.5 \mu \mathrm{g} / \mathrm{mL}$ LPS was $5380 \mathrm{pg} / \mathrm{mL}$ of TNF- $\alpha$, and to $9 \mu \mathrm{g} /$ 
$\mathrm{mL}$ LPS, it was $5570 \mathrm{pg} / \mathrm{mL}$ of TNF- $\alpha$. Although both concentrations induced inflammation, the LPS concentration of $7.5 \mu \mathrm{g} / \mathrm{mL}$ was chosen because inflammation was already induced at this low concentration compared to the concentration of $9 \mu \mathrm{g} / \mathrm{mL}$.

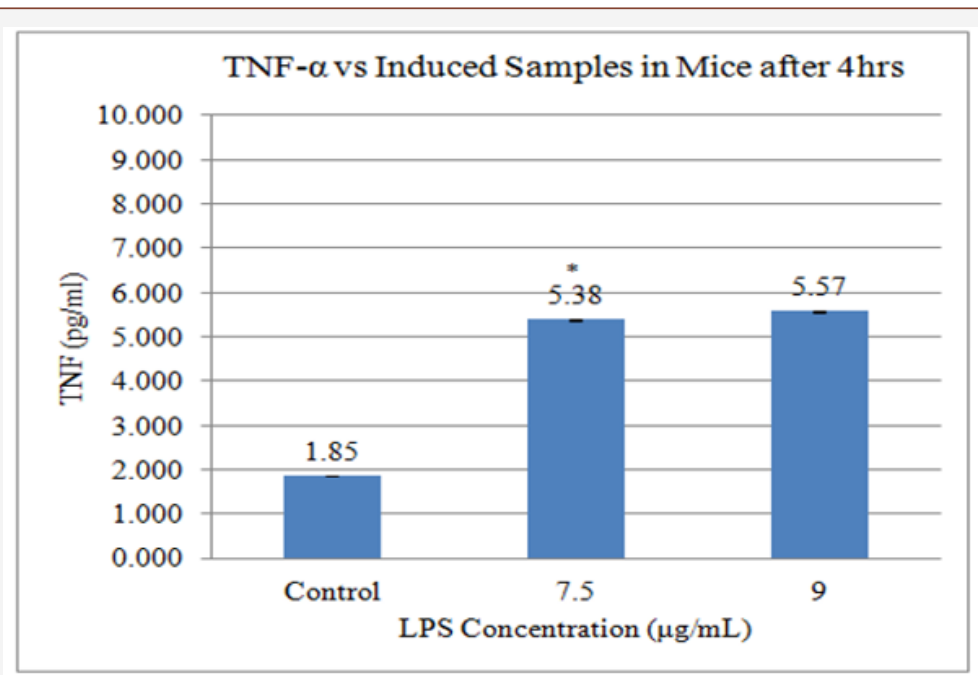

Figure 2:TNF- $\alpha$ responds after 4 hours LPS induction in mice.

Previous studies have shown that an infusion of $9 \mu \mathrm{g} / \mathrm{mL}$ LPS (E. coli 0114) in mice produces, on average, $7510 \mathrm{pg} / \mathrm{mL}$ of IL-1 and $5980 \mathrm{pg} / \mathrm{mL}$ of TNF- $\alpha$ [39]. Therefore, $7.5 \mu \mathrm{g} / \mathrm{mL}$ LPS was selected for further experimentation.

\section{Determination of suitable response time for niosome- encapsulated bromelain to reduce inflammation}

This experiment was carried out to determine the time taken for the elimination of inflammation treated by niosome-encapsulated $10 \%$ bromelain through the responses of IL- 6 and TNF- $\alpha$. In this regard, the concentrations of IL- 6 and TNF- $\alpha$ were measured for 15 minutes for a duration of 120 minutes (Table 2 and Figure 3).
Table 2: The best topical delivery time of noisome.

\begin{tabular}{|c|c|}
\hline Time(min) & pg/ml \\
\hline 15 & 0.839 \\
\hline 30 & 0.796 \\
\hline 45 & 0.801 \\
\hline 60 & 0.805 \\
\hline 75 & 0.808 \\
\hline 90 & 0.813 \\
\hline 105 & 0.818 \\
\hline 120 & 0.822 \\
\hline
\end{tabular}

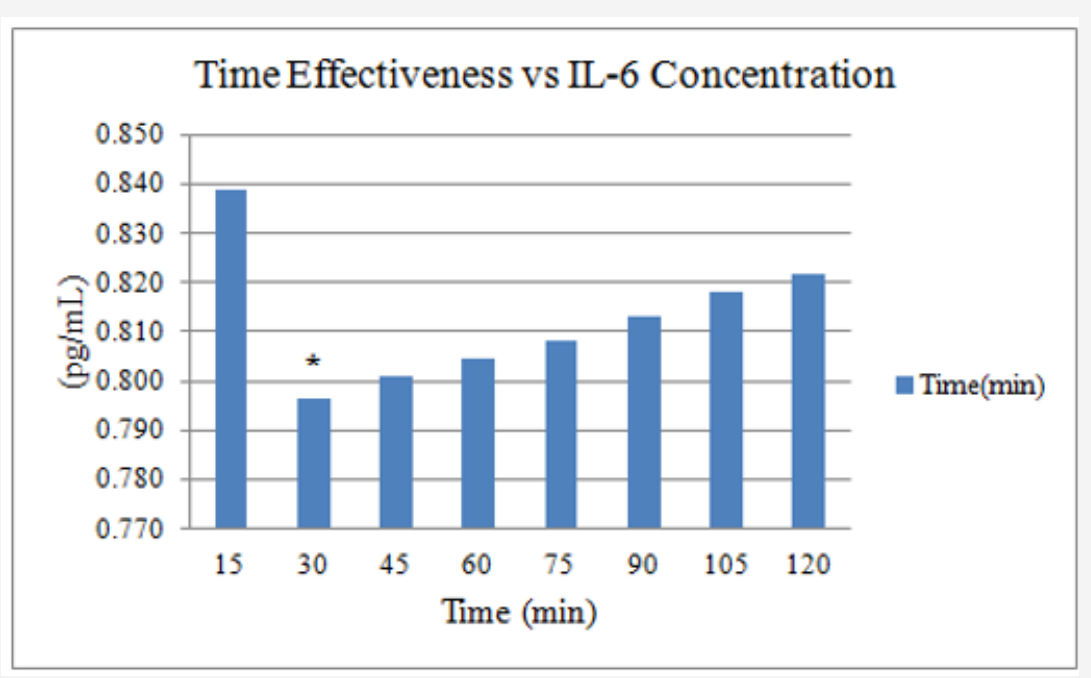

Figure 3:The IL-6 concentration for 20mg niosome encapsulated with $10 \%$ bromelain at every 15 minutes.

Figure 3 shows the effectiveness period for $20 \mathrm{mg}$ of niosomeencapsulated $10 \%$ bromelain measured according to the response of IL-6 every 15 minutes (from 15 until 120 minutes). The concentration of IL-6 increased with time after treatment with niosome-encapsulated $10 \%$ bromelain. However, the best consumption time with the niosome-encapsulated $10 \%$ bromelain for IL-6 was after 30 minutes (Table 3 and Figure 4).

Figure 4 shows the effectiveness time for $20 \mathrm{mg}$ of niosomeencapsulated $10 \%$ bromelain measured according to the response of TNF- $\alpha$ every 15 minutes (from 15 until 120 minutes). The 
concentration of TNF- $\alpha$ increased with time after treatment with niosome-encapsulated $10 \%$ bromelain. However, the best consumption time with niosome-encapsulated $10 \%$ bromelain for TNF- $\alpha$ was after 30 minutes. The aim of this experiment was to select the best delivery time of niosome-encapsulated $10 \%$ bromelain for the elimination of inflammation on the skin around the knees of mice produced by $7.5 \mu \mathrm{g} / \mathrm{mL}$ LPS-induced inflammation.

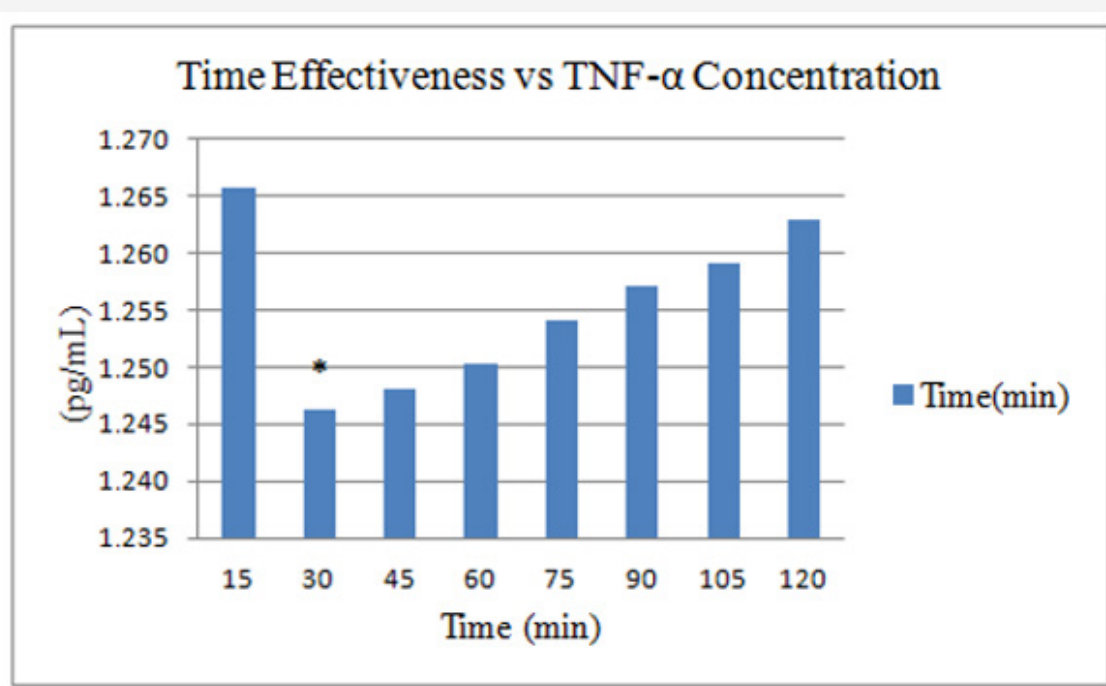

Figure 4:The TNF- $\alpha$ concentration for $20 \mathrm{mg}$ niosome encapsulated with $10 \%$ bromelainat every $15 \mathrm{~min}$..

Table 3: The best topical delivery time of noisome.

\begin{tabular}{|c|c|}
\hline Time(min) & $\mathbf{p g} / \mathbf{m l}$ \\
\hline 15 & 1.266 \\
\hline 30 & 1.246 \\
\hline 45 & 1.248 \\
\hline 60 & 1.25 \\
\hline 75 & 1.254 \\
\hline 90 & 1.257 \\
\hline 105 & 1.259 \\
\hline 120 & 1.263 \\
\hline
\end{tabular}

\section{Determination of the effectiveness of niosome- encapsulated bromelain on LPS-induced inflammation}

This study was carried out to assess the effectiveness of niosome-encapsulated $10 \%$ bromelain in treating inflammation in the skin around the knees of mice when induced by $7.5 \mu \mathrm{g} /$ mLLPS. In this regard, treatments with niosome-encapsulated $10 \%$ bromelain, bromelain alone, base cream, and hydrocortisone as anon-steroidal anti-inflammatory drug (NSAID) were performed (Figure 5).

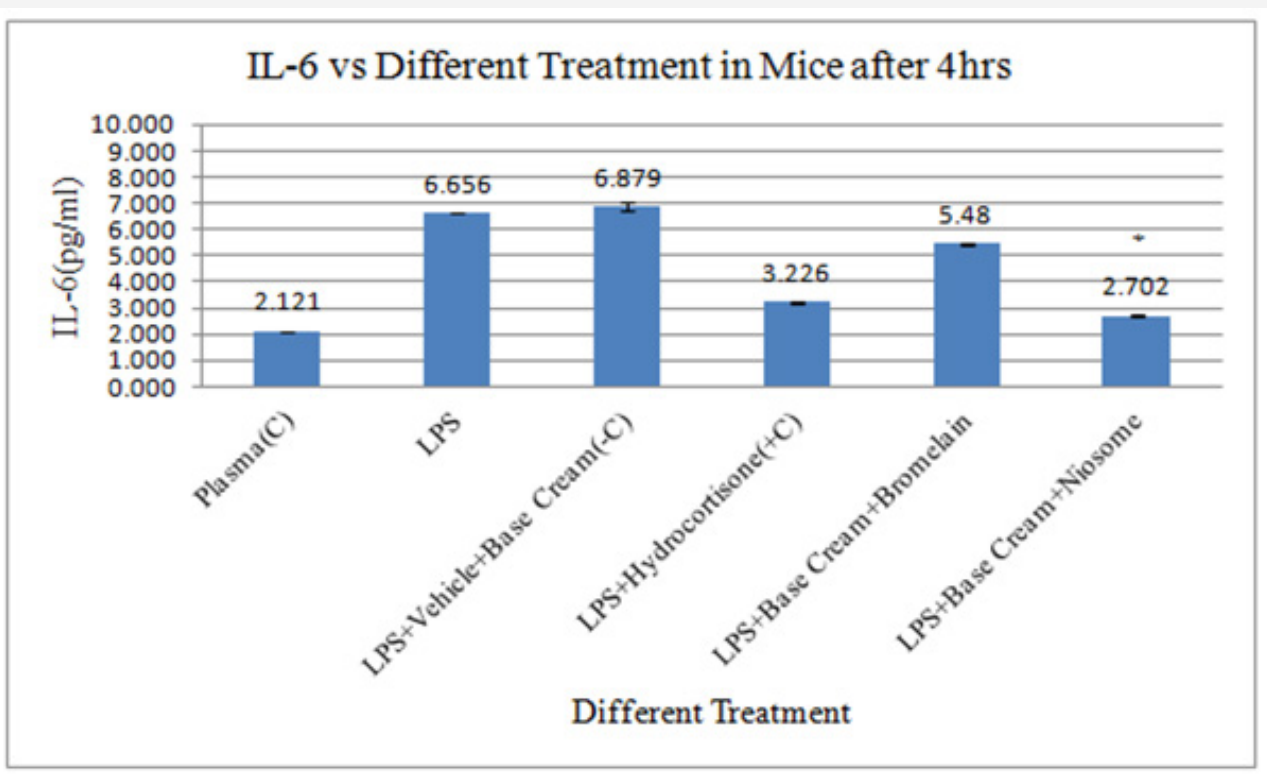

Figure 5:IL-6 respondsof different treatment after 4hin mice.

Figure 5 shows the IL- 6 response against the treatments of niosome-encapsulated $10 \%$ bromelain, without bromelain (vehicle), and bromelain alone. As indicated, the response towards theniosome-encapsulated bromelain, bromelain (vehicle) and bromelain was $2702 \mathrm{pg} / \mathrm{mL}, 6879 \mathrm{pg} / \mathrm{mL}$, and $5480 \mathrm{pg} /$ $\mathrm{mL}$, respectively. Hydrocortisone produced a better result than bromelain since the response was $3226 \mathrm{pg} / \mathrm{mL}$ (Figure 6). 
Figure 6 shows the TNF $\alpha$ response against the treatments with niosome-encapsulated $10 \%$ bromelain, without bromelain (vehicle), and bromelain alone. The responses were $2197 \mathrm{pg} /$ $\mathrm{mL}, 5216 \mathrm{pg} / \mathrm{mL}$, and $3286 \mathrm{pg} / \mathrm{mL}$, respectively. The response of hydrocortisone was $2655 \mathrm{pg} / \mathrm{mL}$, which was better than that of bromelain. The results showed that niosome-encapsulated $10 \%$ bromelain is the best treatment for LPS-induced inflammation, and it is even better than hydrocortisone, a well-known antiinflammatory drug. On the other hand, the experimental effect of niosome alone suggested that the anti-inflammatory properties of bromelain were not dependent on the presence of the vehicle [40].

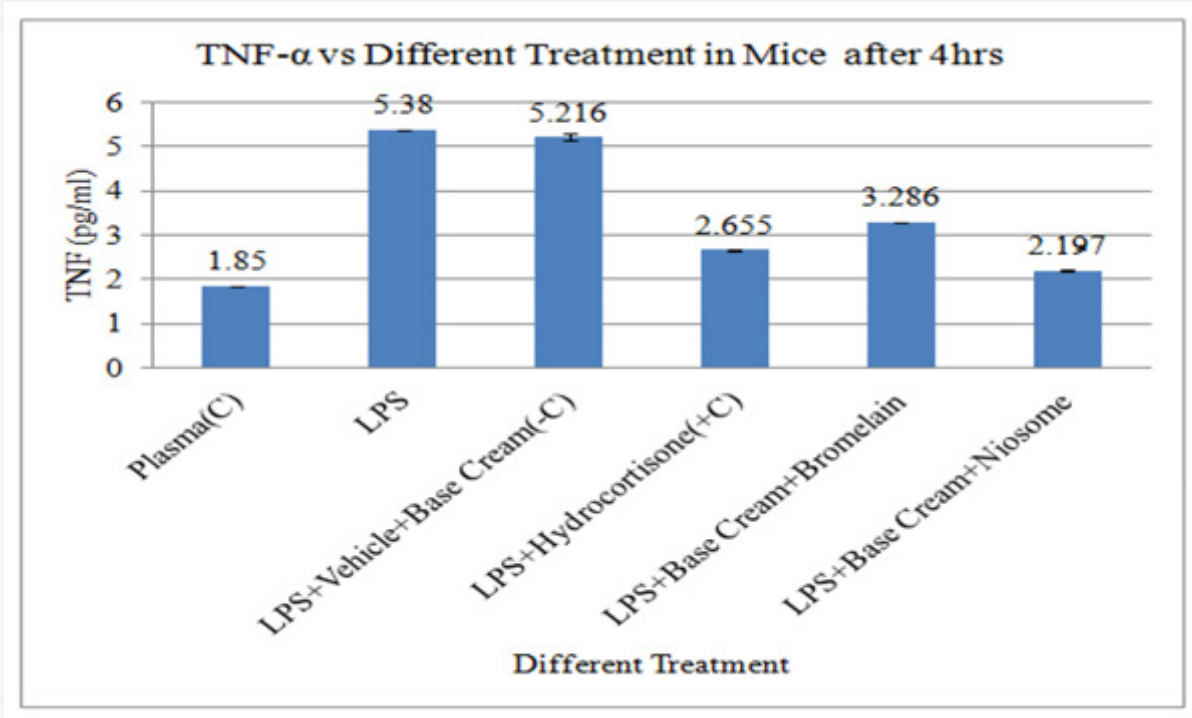

Figure 6:TNF- $\alpha$ respondsof different treatment after 4hin mice.

A statistical analysis of niosome-encapsulated $10 \%$ bromelain showed a significant difference when compared to other treatments with niosome, where $\mathrm{P}<0.05$. According to the results that were obtained, it could be suggested that niosome affected the permeation of bromelain into the skin around the knee area of mice. As such, these results achieved the objective of this research, which was to evaluate the efficacy of a bromelain-niosome system on inflammation in the skin around the knee of mice. Following the administration of $7.5 \mu \mathrm{g} / \mathrm{mL}$ LPS for 4 hours, inflammation was eliminated after 30 minutes with the use of niosome-encapsulated $10 \%$ bromelain. Meanwhile, there were no significant differences among the replications in the different groups. Although the preliminary results showed that the administration of a low dose of LPS produced no obvious inflammation, it was detected by immunemodulatory regulators. This finding is identical to that reported by Godin et al. (1996) [41] and Van Zee et al. (1995) [42]. However, only a limited amount of in-vivo data is available for bromelain and no studies have evaluated its effects on anti-inflammatory cytokine responses in animals. Uchi et al. (2002) [43] showed that bromelain impairs LPS-induced TNF- $\alpha$ production in human monocytederived dendritic cells. Although this research supports the antiinflammatory properties of bromelain, the anti-inflammatory effects could be the result of multiple inhibitions on the inflammatory response. So far, no evaluation of the pharmacokinetics of bromelain in mice is available. In one study that investigated the immune-stimulatory activity of Panax quinquefolius extracts containing bromelain compounds, significant TNF- $\alpha$ stimulating activity was observed [44]. Other pro-inflammatory mediators including chemokines (MIP-2), plasma enzyme mediators, and lipid mediators (COX, PG, and platelet activating factors) may be affected rather than cytokines $[45,46]$.This mice model is identical to other studies of LPS and thrombotic disease [47], atherosclerosis [48], and cell kinetics [49]. A similar pattern was observed with antiinflammatory cytokines and chemokines, i.e., it peaked at 4 hours [50]. Generally, the results of this study showed that the treatments tested could inhibit the inflammatory cytokine responses. However, only a cell type had been used in the culture studies, whereas many cell types are capable of producing anti-inflammatory cytokines in animals. Additionally, other inflammatory mediators may influence the cytokine response.Additional key factors that should be considered are the metabolism and the distribution of the constituent compounds. In summary, this work described the novel action of niosome-encapsulated $10 \%$ bromelain in stimulating an innate anti-inflammatory response.

\section{Statistical Analysis}

In this experiment, two pairs of samples were compared using the t-Test because these two groups contributed a pair of scores. This statistical technique is often called a paired sample t-test or correlated t-test which tells whether there is a statistically significant difference in the mean scores for niosome-encapsulated bromelain and other treatments. When $\mathrm{P}<0.05$, it means that there is a significant difference.

\section{Conclusion}

This study was carried out with the aim of assessing the importance of niosome-encapsulated bromelain in the elimination of inflammation in the skin around the knees of mice infected by 
LPS-induced inflammation. The result showed that niosomeencapsulated $10 \%$ bromelain significantly reduced the levels of IL- 6 and TNF- $\alpha$ in LPS-induced inflammation in mice after 4 hours post treatment as compared to non-encapsulated bromelain and the vehicle.

\section{Acknowledgement}

This work was funded by grants from the research university grant (RUG)(03H95) and NRGS from ministry of agriculture (4H016) Tissue Culture Research Engineering Lab.,N19 Block, Faculty of Chemical Engieering, Universiti Teknologi Malaysia, Malaysia.

\section{Conflict of Interest}

The authors confirm that there are no conflicts of interest.

\section{References}

1. Mangesi L, Zakarija Grkovic I (2016) Treatments for breast engorgement during lactation. Cochrane Database Syst Rev (6): CD00694.

2. Brien S, Lewith G, Walker A, Middleton R, Prescott P, et al. (2006) Bromelain as an adjunctive treatment for moderate-to-severe osteoarthritis of the knee: a randomized placebo-controlled pilot study. QJM 99 (12): 841-850.

3. Klein G, Kullich W, Schnitker J, Schwann, H (2006) Efficacy and tolerance of an oral enzyme combination in painful osteoarthritis of the hip.A double-blind, randomised study comparing oral enzymes with nonsteroidal anti-inflammatory drugs. Clin Exp Rheumatol 24(1): 25-30.

4. Guo R, Canter PH, Ernst E (2006) Herbal medicines for the treatment of rhinosinusitis: a systematic review. Otolaryngol Head Neck Surg 135(4): 496-506

5. Shahid S, Turakhia N, Kundra M, Shanbag P, Daftary G, et al. (2002). Efficacy and safety of Phlogenzym-A protease formulation, in sepsis in children. J Assoc Physicians India 50: 527-531.

6. Lotti T, Mirone V, Imbimbo C, Corrado F, Corrado G, et al. (1993) Controlled clinical studies of nimesulide in the treatment of urogenital inflammation. Drugs46(1): 144-146.

7. Maurer H R (2001) Bromelain: biochemistry, pharmacology and medical use. Cell Mol Life Sci 58(9): 1234-1245.

8. Huang JR, Wu C C, Hou R CW, Jeng K C (2008) Bromelain inhibits lipopolysaccharide-induced cytokine production in human THP-1 monocytes via the removal of CD14. Immunol Invest 37 (4): 263-277.

9. Hou R C W, Chen Y S, Huang J R, Jeng K C G (2006) Cross-linked bromelain inhibits lipopolysaccharide-induced cytokine production involving cellular signaling suppression in rats. J Agric Food Chem 54 (6): 21932198.

10. Balkwill F, Charles KA, Mantovani A (2005) Smoldering and polarized inflammation in the initiation and promotion of malignant disease. Cancer Cell 7(3): 211-217.

11. Yoshimura A, (2006) Signal transduction of inflammatory cytokines and tumor development. Cancer Sci 97 (6): 439-447.

12. Qin Z, Blankenstein T, (2000) CD4+ T Cell-Mediated Tumor Rejection Involves Inhibition of Angiogenesis that Is Dependent on IFN $\gamma$ Receptor Expression by Nonhematopoietic Cells. Immunity 12(6): 677-686.

13. Heuschkel S, Goebel A, Neubert RH (2008) Microemulsions-modern colloidal carrier for dermal and transdermal drug delivery. J Pharm Sci 97(2): 603-631.

14. Desser L, Rehberger A, Kokron E, Paukovits W (1993) Cytokine synthesis in human peripheral blood mononuclear cells after oral administration of polyenzyme preparations. Oncology 50(6): 403-407.

15. Desser L, Rehberger A, Paukovits W (1994) Proteolytic enzymes and amylase induce cytokine production in human peripheral blood mononuclear cells in vitro. Cancer Biother 9(3): 253-263.
16. Barth H, Guseo A, Klein R (2005) In vitro study on the immunological effect of bromelain and trypsin on mononuclear cells from humans. Eur J Med Res 10(8): 325-331.

17. Engwerda CR, Andrew D, Murphy M, Mynott TL (2001) Bromelain Activates Murine Macrophages and Natural Killer Cells in vitro. Cell Immunol 210(1): 5-10.

18. Chobotova K, Vernallis AB, Majid FA (2010) Bromelain's activity and potential as an anti-cancer agent: current evidence and perspectives. Cancer Lett 290(2): 148-156.

19. Onken JE, Greer PK, Calingaert B, Hale LP (2008) Bromelain treatment decreases secretion of pro-inflammatory cytokines and chemokines by colon biopsies in vitro. Clin Immunol 126(3): 345-352.

20. Bauer J, Herrmann F (1991) Interleukin-6 in clinical medicine. Ann Hematol 62(6): 203-210.

21. Manconi M, Sinico C, Valenti D, Lai F, Fadda AM (2006) Niosomes as carriers for tretinoin III. A study into the in vitro cutaneous delivery of vesicle-incorporated tretinoin. Int J Pharm 311(1-2): 11-19.

22. Poltorak A, He X, Smirnova I, Liu MY, Van Huffel C, et al. (1998) “Defective LPS Signaling in $\mathrm{C} 3 \mathrm{H} / \mathrm{HeJ}$ and $\mathrm{C} 57 \mathrm{BL} / 10 \mathrm{ScCr}$ Mice: Mutations in Tlr4 Gene". Science 282(5396): 2085-2088.

23. Madison K C (2003) Barrier function of the skin: "La Raison d'Etre" of the epidermis. J Invest Dermatol 121(2): 231-241.

24. Torchilin V P (2005) Fluorescence microscopy to follow the targeting of liposomes and micelles to cells and their intracellular fate. Adv Drug Deliv Rev 57(1): 95-109.

25. Farkas E, Schubert R, Zelko R (2004) Effect of beta-sitosterol on the characteristics of vesicular gels containing chlorhexidine. Int J Pharm 278(1): 63-70.

26. Shen CY, Rao P V, Batich C D, Moorhead J, Yan J (1994) Stochastic Modeling of Controlled-Release from Poly-Styrene-Co-4-Vinylpyridine Microspheres. Journal of Controlled Release 32(2): 139-146.

27. Mozafari RM (2005) Nanoliposomes from Fundamentals to Recent Developments: Oxford, UK. Trafford Pub Ltd.

28. Kogan A, Garti N (2006) Microemulsions as transdermal drug delivery vehicles. Adv Colloid Interface Sci 123-126: 369-385.

29. Patel GB, Omri A, Deschatelets L, Sprott GD (2002) Safety of archaeosome adjuvants evaluated in a mouse model. J Liposome Res, 12(4): 353-372.

30. Ravi Kumar MN, Bakowsky U, Lehr CM (2004) Preparation and characterization of cationic PLGA nanospheres as DNA carriers. Biomaterials 25(10): 1771-1777.

31. Teixeira M, Alonso MJ, Pinto MM, Barbosa CM (2005) Development and characterization of PLGA nanospheres and nanocapsules containing xanthone and 3-methoxyxanthone. European Journal of Pharmaceutics and Biopharmaceutics 59(3): 491-500.

32. Escobar Chavez J J, Rodriguez Cruz I M, Dominguez Delgado CL, Diaz Torres, Revilla Vazquez, et al.(2012) Nanocarrier Systems for Transdermal Drug Delivery. Recent Advances in Novel Drug Carrier Systems 51(8): 978-953.

33. Palozza P, Muzzalupo R, Trombino S, Valdannini A, Picci N (2006) Solubilization and stabilization of beta-carotene in niosomes: delivery to cultured cells. Chem Phys Lipids 139(1): 32-42.

34. Brouckaert P, Libert C, Everaerdt B, Takahashi N, Cauwels A, et al. (1993) Tumor necrosis factor, its receptors and the connection with interleukin 1 and interleukin 6. Immunobiology 187(3-5): 317-329.

35. Alsarra IA, Bosela AA, Ahmed SM, Mahrous GM (2005) Proniosomes as a drug carrier for transdermal delivery of ketorolac. Eur J Pharm Biopharm 59(3): 485-490.

36. Mynott TL, Crossett B, Prathalingam SR (2002) Proteolytic inhibition of Salmonella enterica serovar typhimurium-induced activation of the mitogen-activated protein kinases ERK and JNK in cultured human intestinal cells. Infect Immun 70(1): 86-95.

37. Arora R, Sharma A (2010) Release studies of ketoprofenniosome formulation. Journal of Chemical and Pharmaceutical Research 2: 79-82. 
38. Freshney B C (2008) Transdermal drug delivery-What to expect in the near future. Business briefing: Pharma tech 192-193.

39. Nasr M, Mansour S, Mortada ND, Elshamy AA (2008) Vesicular aceclofenac systems: a comparative study between liposomes and niosomes. J Microencapsul 25(7): 499-512.

40. Rajiv J, Hardik J, Vaibhav S, Vimal A (2011) Nanoburrs: a novel approach in the treatment of cardiovascular disease. Int Res J Pharm 2: 91-92.

41. Greenspan P, Fowler SD (1985) Spectrofluorometric studies of the lipid probe, nile red. J Lipid Res 26(7): 781-789.

42. Van Zee KJ, Coyle SM, Calvano SE, Oldenburg HS, Stiles DM, et al. (1995) Influence of IL-1 receptor blockade on the human response to endotoxemia. J Immunol 154(3): 1499-1507.

43. Onken JE, Greer PK, Calingaert B, Hale LP (2008) Bromelain treatment decreases secretion of pro-inflammatory cytokines and chemokines by colon biopsies in vitro. Clin Immunol 126(3): 345-352.

44. Schmidt M, Christiansen CF, Mehnert F, Rothman KJ, Sorensen HT ( 2011) Non-steroidal anti-inflammatory drug use and risk of atrial fibrillation or flutter: population based case-control study. BMJ 343-345.
45. Marieb E N (2007) Essentials of Human Anatomy and Physiology. California: Benjamin Cummings Publishing Company.

46. Lee MY, Dordick JS (2002) Enzyme activation for nonaqueous media. Curr Opin Biotechnol 13(4): 376-384

47. Hundsberger H, Verin A, Wiesner C, Pfluger M, Dulebo A, et al. (2008) TNF: a moonlighting protein at the interface between cancer and infection. Front Biosci 13: 5374-5386.

48. Hao YM, Li K (2011) Entrapment and release difference resulting from hydrogen bonding interactions in niosome. Int J Pharm 403(1-2): 245253.

49. Bhatnagar P, Gupta K Ch (2013) Oral Administration of Eudragit Coated Bromelain encapsulated PLGA Nanoparticles for Effective Delivery of Bromelain for Chemotherapy in vivo. 29th Southern Biomedical Engineering Conference.

50. Abbas A K, Lichtman A H H, Pillai S (2012) Innate Immunity in Basic Immunology: Functions and Disorders of the Immune System. Philadelphia. 